\title{
Interleukin-1 Receptor Antagonist and Tumor Necrosis Factor Binding Protein Decrease Osteoclast Formation and Bone Resorption in Ovariectomized Mice
}

\author{
Riko Kitazawa, Robert B. Kimble, James L. Vannice, ${ }^{\star}$ Viola T. Kung, ${ }^{\star}$ and Roberto Pacifici \\ Division of Bone and Mineral Diseases, Washington University School of Medicine and The Jewish Hospital of St. Louis, St. Louis, \\ Missouri 63110; *Synergen Inc., Boulder, Colorado 80301; and ${ }^{\ddagger}$ Metra Biosystems Palo Alto, California 94304
}

\begin{abstract}
To investigate the contribution of IL-1, IL-6, and TNF to the increased osteoclastogenesis induced by estrogen deficiency, ovariectomized (ovx) mice were treated with either IL-1 receptor antagonist (IL-1ra), a competitive inhibitor of IL1, TNF binding protein (TNFbp), an inhibitor of TNF, or the anti-IL-6 antibody (Ab) 20F3 for the first 2 wk after surgery. ovx increased the bone marrow cells secretion of IL-1 and TNF, but not IL-6, and the formation of TRAPpositive osteoclast-like multinucleated cells (MNCs) in bone marrow cultures treated with $1,25(\mathrm{OH})_{2} \mathrm{D}_{3}$. The increase in MNC formation induced by ovx was prevented by in vivo treatment with either $17 \beta$ estradiol, IL-1ra, TNFbp, or antiIL-6 Ab. However, the percent change in MNC formation induced by the anti-IL-6 Ab was similar in ovx and shamoperated animals, whereas IL-1ra and TNFbp were effective only in ovx mice. MNC formation was also decreased by in vitro treatment of bone marrow cultures with IL-1ra and TNFbp, but not with anti-IL-6 Ab. Ovx also increased bone resorption in vivo and in vitro, as assessed by the urinary excretion of pyridinoline cross links and the formation of resorption pits, respectively. IL-1ra, TNFbp and estrogen decreased bone resorption in vivo and in vitro whereas the anti-IL-6 Ab inhibited bone resorption in vitro but not in vivo. In conclusion, these data indicate that $I L-1$ and TNF play a direct role in mediating the effects of ovx on osteoclastogenesis and bone resorption. The data also suggest that IL-6 is not essential for increasing bone resorption in the early postovariectomy period. (J. Clin. Invest. 1994. 94:2397-2406.) Key words: osteoporosis - interleukin 1 • interleukin $6 \cdot$ tumor necrosis factor • cytokines • ovariectomy
\end{abstract}

\section{Introduction}

Postmenopausal osteoporosis is a disorder characterized by a progressive loss of bone tissue which begins after natural or surgical menopause and leads to the occurrence of spontaneous fractures (1). Although estrogen deficiency is known to cause bone loss by stimulating the resorptive activity of mature osteo-

Address correspondence to Roberto Pacifici, M.D., Division of Bone and Mineral Diseases, The Jewish hospital of St. Louis, 216 S. Kingshighway, St. Louis MO 63110.

Received for publication 7 April 1994 and in revised form 1 August 1994.

J. Clin. Invest.

(c) The American Society for Clinical Investigation, Inc.

0021-9738/94/12/2397/10 \$2.00

Volume 94, December 1994, 2397-2406 clasts $(\mathrm{OCs})^{1}$ and the proliferation and differentiation of $\mathrm{OC}$ precursors (2), the mechanism of these effects is still conjectural at best. One such mechanism may be a modulatory effect on the secretion of factors that are produced in the bone microenvironment and influence bone remodeling $(2,3)$. Among these are IL-1 (4-6), IL-6 (7-9), and tumor necrosis factor $\alpha$ and $\beta$ (TNF) $(10,11)$. IL-1 and TNF promote bone resorption in vitro $(4,5,12)$ and in vivo (13-16) by activating mature OCs indirectly, via a primary effect on osteoblasts $(15,17)$, and by stimulating the proliferation and differentiation of OC precursors $(18,19)$. When bound to the $80-\mathrm{kD}$ binding chain of the IL- 6 receptor, IL-6 also increases OC formation from hemopoietic precursors (20). However, IL-6 does not activate mature OCs (21). As a result, IL-6 stimulates bone resorption only in systems rich in OC precursors, such as the mouse fetal metacarpals (22).

The multiple and potent effects of these factors on bone resorption and the discovery of estrogen receptors in stromal cells $(23)$, osteoblasts $(24,25)$ OCs $(26,27)$, and macrophages (28), suggest that estrogen may modulate bone resorption and osteoclastogenesis by regulating the release of cytokines in the bone microenvironment. Several lines of evidence support this hypothesis. First, the expression of IL- 1 and IL- 6 mRNA is increased in bone cells from postmenopausal women (29). Second, previous observations of ours (30-32) and others (10,3335 ) demonstrate that both natural and surgical menopause are associated with an increased monocytic production of IL-1, IL6 , and TNF which is blocked by estrogen replacement. Third, the simultaneous inhibition of IL-1 and TNF $\alpha$ normalizes the bone resorption activity of monocyte supernatants obtained from postmenopausal women (36). Fourth, the block of IL-1 and IL-6, prevents bone loss in ovariectomized (ovx) rats (37) and decreases OC formation in ovx mice (8), respectively. However, in spite of these observations, the relative importance of each cytokine and the mechanism by which they control bone resorption and osteoclastogenesis remains to be elucidated because of the large number of factors involved and their overlapping effects on bone remodeling $(7,10)$.

The recent discovery of specific cytokine antagonists has made it possible to block the activity of these factors for prolonged periods of time and to investigate the role of cytokines in many diseases (38). Among these inhibitors are the IL-1 inhibitor, IL-1 receptor antagonist (IL-1 ra), and the TNF inhibitor, TNF binding protein (TNFbp). Human IL-1 ra is a recombinant $17-\mathrm{kD}$ protein which shares $26 \%$ sequence homology with IL-1 $\beta(39,40)$. IL- 1 ra binds to IL- 1 receptors and competes with both IL- $1 \alpha$ and IL- $1 \beta$ without detectable IL- 1 agonistic effects $(41,42)$. TNFbp is a specific TNF inhibitor made of two molecules of the extracellular domain of the human type I TNF

\footnotetext{
1. Abbreviations used in this paper: $\mathrm{Ab}$, antibody; IL-1 ra, Interleukin 1 receptor antagonist; MNCs, osteoclast-like multinucleated cells; OC, osteoclast; ovx ovariectomy; r, recombinant; TNFbp, TNF binding protein; TRAP, tartrate resistant acid phosphatase.
} 
receptor added to both ends of a molecule of polyethylene glycol. TNFbp binds with equal affinity to TNF $\alpha$ and TNF $\beta$.

In a recent study we have used IL-1ra to demonstrate that the functional block of IL-1 decreases bone loss and bone resorption in ovx rats (37). In this study we have treated ovx mice with IL-1ra, TNFbp and the anti-IL-6 Ab 20F3 to investigate the role of IL-1, TNF $\alpha$ and IL- 6 on the enhanced formation of osteoclast-like multinucleated cells (MNCs) and the increased bone resorption induced by estrogen deficiency.

\section{Methods}

Unless otherwise specified, reagents and media were from Sigma Chemical Co. (St. Louis MO).

Study protocol. 5-wk-old C3H/Hen mice (Jackson Laboratory, Bar Harbor, ME) were ovx or sham-operated by the dorsal approach under general anesthesia. Based on the results of preliminary dose-response studies (not shown) ovx mice were treated with either $17 \beta$ estradiol $(0.16 \mu \mathrm{g} / \mathrm{d}$, the lowest dose which maintains a normal uterine weight), IL-1 ra ( $25 \mu \mathrm{g} / \mathrm{KgBW}$ per day), TNFbp ( $1 \mathrm{mg} / \mathrm{KgBW}$ per day), the antiIL-6 Ab 20F3 (1 mg/wk), IL-1ra vehicle, TNFbp vehicle, irrelevant rat anti-mouse IgG (Organon Teknika Corp., West Chester, PA) or a combination of these agents. Sham-operated mice were treated with each of the above substances, except estrogen. For some experiments ovx and sham-operated mice were also treated with $25 \mathrm{mg} / \mathrm{KgBW}$ per day bovine serum albumin (BSA). IL-1 ra and TNFbp were kindly provided by Synergen Inc. Ab 20F3 was a generous gift of John Kenney (Syntex Inc.). All treatments started at the time of surgery and continued for 2 wk. IL-1ra, IL-1ra vehicle and BSA were administered by implanting Alzet 2002 osmotic pumps (Alza Inc., Palo Alto, CA) in a dorsal subcutaneous pocket at the time of surgery. Anti-IL-6 Ab and irrelevant IgG were administered by weekly intraperitoneal injections. TNFbp and TNFbp vehicle were injected subcutaneously every other day. Estrogen was delivered by slow releasing subcutaneous pellets (Innovative Research of America, Toledo, $\mathrm{OH}$ ) implanted in a nuchal subcutaneous pocket. None of the mice exhibited evidence of infectious disease, impaired growth, immunosuppression or other side effects caused by the treatments. This protocol was approved by the Animal Care and Use Committee of the Jewish Hospital of St. Louis.

Bone marrow cell cultures. Bone marrow cultures were prepared using previously described methods (43) with modifications. Briefly, at time of death, the bone marrow was flushed from femurs and tibiae with ice-cold alpha-minimal essential media ( $\alpha$-MEM). The cells were collected, pelleted, resuspended in $\alpha$-MEM supplemented with $10 \%$ fetal bovine serum (FBS) (GIBCO-BRL, Grand Island, NY), and cultured in multiwell plates (Becton Dickinson Labware, Lincoln Park, NY) at a density of $2.5 \times 10^{6} / \mathrm{cm}^{2}$ for $7 \mathrm{~d}$ in presence of $10 \mathrm{nM} 1,25(\mathrm{OH})_{2} \mathrm{D}_{3}$. At $4 \mathrm{~d}$ of culture, $90 \%$ of the medium was replaced and $1,25(\mathrm{OH})_{2} \mathrm{D}_{3}$ added again at the same concentration.

Characterization of osteoclast-like multinucleated cells. At the end of the culture period, cells were fixed and stained for tartrate resistant acid phosphatase (TRAP) using a commercial kit. TRAP-positive cells with three or more nuclei were counted as MNCs. Expression of calcitonin receptors was also assessed by autoradiography using ${ }^{125}$ I-salmon calcitonin (Peninsula Laboratories Inc., Belmont, CA), as previously described (44). For this assay aliquots of bone marrow cells were seeded on 12-mm glass coverslips (Fisher scientific Co., Pittsburgh, PA), inserted into 24-well multiwell plates and cultured with $10 \mathrm{nM}$ $1,25(\mathrm{OH})_{2} \mathrm{D}_{3}$ for $7 \mathrm{~d}$. The cells were then incubated with $0.2 \mathrm{nM}{ }^{125} \mathrm{I}$ calcitonin with or without $100 \mathrm{nM}$ cold calcitonin for $1 \mathrm{~h}$ at $4^{\circ} \mathrm{C}$. After washing, the cover slips were stained for TRAP, mounted onto glass slides, dipped in LM-1 emulsion (Amersham, Arlington Heights, IL) exposed at $4^{\circ} \mathrm{C}$ for $1 \mathrm{wk}$, and developed. More than $98 \%$ of the TRAPpositive MNCs formed in the bone marrow cultures showed specific binding of labeled calcitonin (data not shown). Therefore, we regarded the TRAP-positive multinucleated cells formed in the bone marrow cultures as osteoclast-like MNCs.

Resorption pit assay. The osteoclast-like identity of MNCs was further demonstrated by assessing their ability to form resorption pits on human cortical bone slices. For this assay we used the methods of Boyde et al. (45) with modifications. Briefly, bone marrow cells $(2.5 \mathrm{x}$ $10 \% \mathrm{~cm}^{2}$ ) were seeded in triplicate on thin slices of human bone, inserted into 96-well culture plates and cultured for $7 \mathrm{~d}$ as described above. The bone slices were then incubated overnight with $0.25 \mathrm{M}$ ammonium hydroxide and sonicated for $30 \mathrm{~s}$ in PBS. The slices were then stained with $2 \%(\mathrm{wt} / \mathrm{vol})$ toluidine blue in PBS, rinsed and dried. The area of pit resorption was measured in each one of the triplicate cultures using a digitizer-equipped semi-automatic image analyzer (R\&M Biometrics, Nashville, TN). Since the low $\mathrm{pH}$ required for the TRAP staining alters the bone surface, we were unable to measure resorption pits in bone slices stained for TRAP. Consequently, we were unable to express the data as resorbed area/MNC. Results were, therefore, expressed as the mean $\left( \pm\right.$ SEM) of the area resorbed $\left(\mathrm{mm}^{2}\right)$ divided by the total area $\left(\mathrm{mm}^{2}\right)$ of the bone slice.

Pyridinoline cross-links assay. The urinary excretion of pyridinoline cross-links, a marker of bone resorption (46), was measured at the end of the treatment period in urine samples collected between 2:00 and 6:00 PM using an ELISA kit developed by Metra Biosystems (Palo Alto, CA) (47). Briefly, $10 \mu \mathrm{l}$ urine sample and $150 \mu \mathrm{l}$ of rabbit antipyridinoline antiserum were added to a pyridinoline-coated microplate and incubated overnight. After the plates were washed with PBS, 150 $\mu \mathrm{l}$ of goat anti-rabbit IgG alkaline phosphatase conjugate was added to each well. The unbound conjugate was then removed by washing and the enzyme activity measured photometrically by adding an enzyme substrate and using a microplate reader at $405 \mathrm{~nm}$. Results were expressed as $\mathrm{nmol} / \mathrm{mmol}$ urinary creatinine, as measured by a standard colorimetric technique. The intra- and the interassay variation of this method are $<7$ and $<10 \%$, respectively (47).

Cytokine assays. To investigate the effect of ovx on the production of cytokines from bone marrow cells, additional groups of untreated and estrogen-treated mice were subjected to ovx or sham operation as described above and killed $2 \mathrm{wk}$ after surgery. At time of death bone marrow cells were prepared as described above, seeded at $5 \times 10^{6}$ cells/ $\mathrm{ml}$ and cultured for $72 \mathrm{~h}$. IL-1, IL-6, and TNF were measured in the bone marrow cell culture media collected at the end of the culture period. IL-1 bioactivity was measured by assessing the increment in mitogen induced proliferation of the helper T cell D10.G4.1 (D10 cells) as previously described $(30,31,37)$. The sensitivity of this assay was 1 $10 \mathrm{pg} / \mathrm{ml}$. The nature of the assayed material was confirmed as IL-1 by demonstrating inhibition of the conditioned medium effect on the D10 cells proliferation in the presence of $50 \mathrm{ng} / \mathrm{ml} \mathrm{IL-1ra.} \mathrm{IL-} 6$ was measured with a specific double site ELISA (Pharmingen, San Diego, CA). The sensitivity of this assay was $10 \mathrm{pg} / \mathrm{ml}$. TNF was measured by a specific double-site ELISA previously described (48), using antibodies (Pharmingen) which recognize both TNF $\alpha$ and TNF $\beta$. The sensitivity of this assay was $25 \mathrm{pg} / \mathrm{ml}$.

Serum IL-1ra and TNFbp assays. Serum levels of IL-1ra were measured at $2 \mathrm{wk}$ of treatment using a specific ELISA recently described (49). The sensitivity of this assay is $8 \mathrm{pg} / \mathrm{ml}$. The serum levels of TNFbp were estimated indirectly by a specific double-site ELISA (R\& D Systems Inc. Minneapolis, MN) which recognizes the soluble human type I TNF receptor. The sensitivity of this assay is $10 \mathrm{pg} / \mathrm{ml}$.

Assessment of serum neutralization activity. The presence of active IL-1ra in the serum of IL-1 ra-treated mice was determined by assessing the serum obtained from ovx mice at the end of the treatment period against IL- $1 \beta$ augmentation of mitogen-induced proliferation of D10 cells, as previously described (37). Briefly, mouse sera (12.5 $\mu \mathrm{l})$ or IL$1 \mathrm{ra}(2.5 \mathrm{ng})$ were serially diluted (1:2) and added to D10 cells seeded in 96-wells plates. Recombinant ( $\mathrm{r}$ ) human IL-1 $\beta(7.5 \mathrm{pg})$ was then added to each well. This concentration of $\operatorname{rIL}-1 \beta$ was selected because it induces $50 \%$ maximal augmentation in the D10 cell proliferation assay. At the end of a 3-d culture period the D10 cell proliferation was measured as previously described (37). Results were expressed as percent change in D10 cell proliferation.

The presence of active TNFbp and anti-IL-6 Ab in the 2-wk serum of TNFbp- and 20F3 Ab-treated mice was assessed by measuring the ability of the sera to inhibit the binding of rTNF $\alpha$ and rIL-6 to immobi- 
Table I. Effect of Ovariectomy (ovx) and Sham Operation on the Secretion of IL-1 Bioactivity, TNF, and IL-6 (mean \pm SEM) from Bone Marrow Cells

\begin{tabular}{lccc}
\hline & $\begin{array}{c}\text { Untreated } \\
\text { sham-operated }\end{array}$ & $\begin{array}{c}\text { Untreated } \\
\text { ovx }\end{array}$ & $\begin{array}{c}\text { Estrogen } \\
\text { treated ovx }\end{array}$ \\
\hline & $(n=6)$ & $(n=6)$ & $(n=6)$ \\
IL-1 $(\mathrm{U} / \mathrm{ml})$ & $3.9 \pm 0.5$ & $15.2 \pm 0.9^{*}$ & $3.2 \pm 0.3$ \\
TNF $(\mathrm{pg} / \mathrm{ml})$ & $48.3 \pm 10.8$ & $137.0 \pm 20.5^{*}$ & $61.1 \pm 21.4$ \\
IL-6 $(\mathrm{pg} / \mathrm{ml})$ & $7.8 \pm 0.7$ & $10.5 \pm 1.1$ & $12.5 \pm 2.1$ \\
& & & \\
\hline
\end{tabular}

2 wk after ovx or sham operation bone marrow cells were isolated as described in Methods and cultured for $72 \mathrm{~h}$. IL-1 bioactivity was measured in the culture medium with the D10 cell bioassay. The nature of the assayed material was confirmed as IL-1 by demonstrating that the addition of $50 \mathrm{ng} / \mathrm{ml}$ IL-1 ra decreased IL-1 bioactivity to $0.01 \pm 0.01$ $\mathrm{U} / \mathrm{ml}$ (mean \pm SEM) in all samples. IL- 6 and TNF (both $\alpha$ and $\beta$ ) were measured by ELISA. $* P<0.05$ compared with the corresponding group of untreated sham-operated and estrogen treated ovx mice.

lized anti-TNF and anti-IL-6 antibodies, respectively. Briefly, sera (20 $\mu$ l) from ovx mice treated with either TNFbp, Ab 20F3 or control substances and fresh TNFbp $(100 \mathrm{pg} / \mathrm{ml})$ or $\mathrm{Ab} 20 \mathrm{~F} 3(100 \mathrm{ng} / \mathrm{ml})$ were serially diluted (1:2) and incubated with rTNF $\alpha(1 \mathrm{ng} / \mathrm{ml})$ or rIL-6 $(0.6$ $\mathrm{ng} / \mathrm{ml}$ ) for $3 \mathrm{~h}$ at $4^{\circ} \mathrm{C}$ (total volume $200 \mu \mathrm{l}$ ). In parallel, microtiter plate wells were coated with anti-murine TNF $\alpha$ or anti-murine IL- 6 capture antibodies (Pharmingen). Uncoupled binding sites in the wells were blocked with $3.0 \%$ BSA. After washing, the sera previously incubated with the rTNF $\alpha$ or rIL- 6 were transferred to the wells and incubated in triplicate overnight at $4^{\circ} \mathrm{C}$ to allow the binding of free cytokines to the immobilized capture Ab. For detection of TNF $\alpha$ or IL- 6 bound to the capture $\mathrm{Ab}, 10 \mathrm{ng}$ biotinylated anti-TNF or anti-IL- $6 \mathrm{Ab}$ was added to each well for $1 \mathrm{~h}$ and washed three times. The plates were then incubated sequentially with peroxidase-conjugated avidin and ABTS substrate (Boehringer Mannheim Biochemicals, Indianapolis, IN). Color development was assessed at $405 \mathrm{~nm}$ with a Dynatek MR 5000 ELISA reader. Results were expressed as percent O.D. change by arbitrarily setting the OD corresponding to $0.6 \mathrm{ng} / \mathrm{ml} \mathrm{rIL}-6$ or $1 \mathrm{ng} / \mathrm{ml} \mathrm{rTNF} \alpha$ at $100 \%$.

Statistical analysis. The effects of surgery and treatment on MNC formation and bone resorption were analyzed by one-way analysis of variance and Fisher protected LSD test.

\section{Results}

Effect of ovariectomy on the secretion of cytokines from cultured bone marrow cells. Mononuclear cells cultured in polystyrene plates with ordinary tissue culture media (which contains small amounts of LPS) express IL-1, IL-6, and TNF mRNA and secrete small quantities of cytokines (50-52). In accordance with these published data, 2 wk after surgery, bone marrow cells from untreated sham-operated mice were found to secrete measurable amounts of IL-1 bioactivity (which was neutralized by the addition of IL-1ra to the assay system), TNF and IL-6, into the 72-h culture medium (Table I). Ovx increased significantly the production of IL-1 and TNF, but not IL-6, as demonstrated by the finding of higher levels of IL-1 and TNF in the culture media of cells from untreated ovx mice than in those from sham-operated or estrogen treated ovx animals (Table I).

Effect of ovx on osteoclast formation and bone resorption. In preliminary studies (not shown) we have found that when bone marrow cells were cultured in presence of $10 \mathrm{nM}$ $1,25(\mathrm{OH})_{2} \mathrm{D}_{3}$, TRAP-positive mononulear cells developed in the bone marrow cultures after 3-4 d of incubation. TRAP-positive MNCs which resorb bone and express the calcitonin receptor appeared on days 5-6 and reached a peak at day 7 (Fig. 1, A$D$ ). The lack of $1,25(\mathrm{OH})_{2} \mathrm{D}_{3}$ during the first $4 \mathrm{~d}$ of culture did not prevent $\mathrm{MNC}$ formation. In contrast, the withdrawal of $1,25(\mathrm{OH})_{2} \mathrm{D}_{3}$ during the last $3 \mathrm{~d}$ of a 7 -d culture prevented MNC formation, confirming the essential role of $1,25(\mathrm{OH})_{2} \mathrm{D}_{3}$ for the differentiation of MNCs precursors. MNC formation was proportional to the number of seeded cells with an optimal yield at $2.5-5 \times 10^{6}$ cells $/ \mathrm{cm}^{2}$.

Fig. 2 shows the effect of ovx on bone marrow cells and MNC formation. At time of death ( 2 wk after surgery) the number of bone marrow cells derived from untreated ovx mice was $\sim 1.5$ fold higher than that derived from sham-operated mice. At the end of the 7-d-long culture, bone marrow preparations from ovx mice also had a higher numbers of MNCs than cultures from sham-operated mice. This difference was observed when the results were expressed either as $\mathrm{MNCs} / 10^{6}$ bone marrow cells or as MNCs/mouse. Fig. 2 also shows that the effects of ovx were completely prevented by estrogen treatment in vivo.

Time course experiments (not shown) revealed that the earliest time point at which the difference in production of MNCs between sham and ovx mice became significant was $10 \mathrm{~d}$ after surgery. The production of MNCs remained significantly higher in cultures from ovx mice than in those from sham-operated mice for 4 wk after surgery.

To investigate the effects of ovx on bone resorption in vivo, we measured the urinary excretion of pyridinoline cross-links (PYD), a new sensitive marker of resorption activity (46). 2 wk after surgery PYD excretion was (Fig. $3 A$ ) significantly higher in ovx than in sham-operated mice. This increase was completely prevented by estrogen treatment. We then assessed the ability of osteoclast-like cells to form resorption pits in vitro. For these experiments bone marrow cells were harvested 2 wk after ovx or sham operation, seeded on thin slices of human bone and cultured for $7 \mathrm{~d}$. Cells were then removed and the resorption pits visualized by staining the bone slices with toluidine blue. Fig. $3 B$ shows that MNCs formed from untreated ovx mice excavated a larger bone area than those obtained from either untreated sham-operated or estrogen-treated ovx mice. Since the TRAP and the toluidine blue staining cannot be performed in the same culture well, we were unable to determine the resorption area excavated by individual OCs. However, when the effects of ovx on MNC formation and on resorption pits formation were examined in parallel cultures, we found that the magnitude of the increase in the resorbed area was similar to the increase in the number of MNCs. These findings suggest that the increase in pit formation induced by ovx was primarily due to an increase in number of MNCs, rather than to an increased resorption activity of each OC.

Effect of in vivo and in vitro treatment with IL-1 ra, TNFbp, and anti-IL-6 Ab on OC formation. To investigate the effects of in vivo treatment with IL-1 ra, TNFbp, and anti-IL-6 Ab on OC formation, ovx and sham-operated mice were treated with these substances for $2 \mathrm{wk}$, beginning at the time of surgery. IL1 ra and type I TNF receptor, as measured by specific ELISAs, were not detectable in the sera of vehicle treated mice. In contrast, at $2 \mathrm{wk}$, mice treated with IL-1 ra or TNFbp had serum IL-1 ra and type I TNF receptor levels of $1.58+0.20 \mu \mathrm{g} / \mathrm{ml}$ and $134.2+35.5 \mathrm{pg} / \mathrm{ml}$, respectively. Proliferation neutralization assays also demonstrated that the serum of IL-1 ra treated mice inhibited IL- $1 \beta$-induced augmentation of D10 cells proliferation 

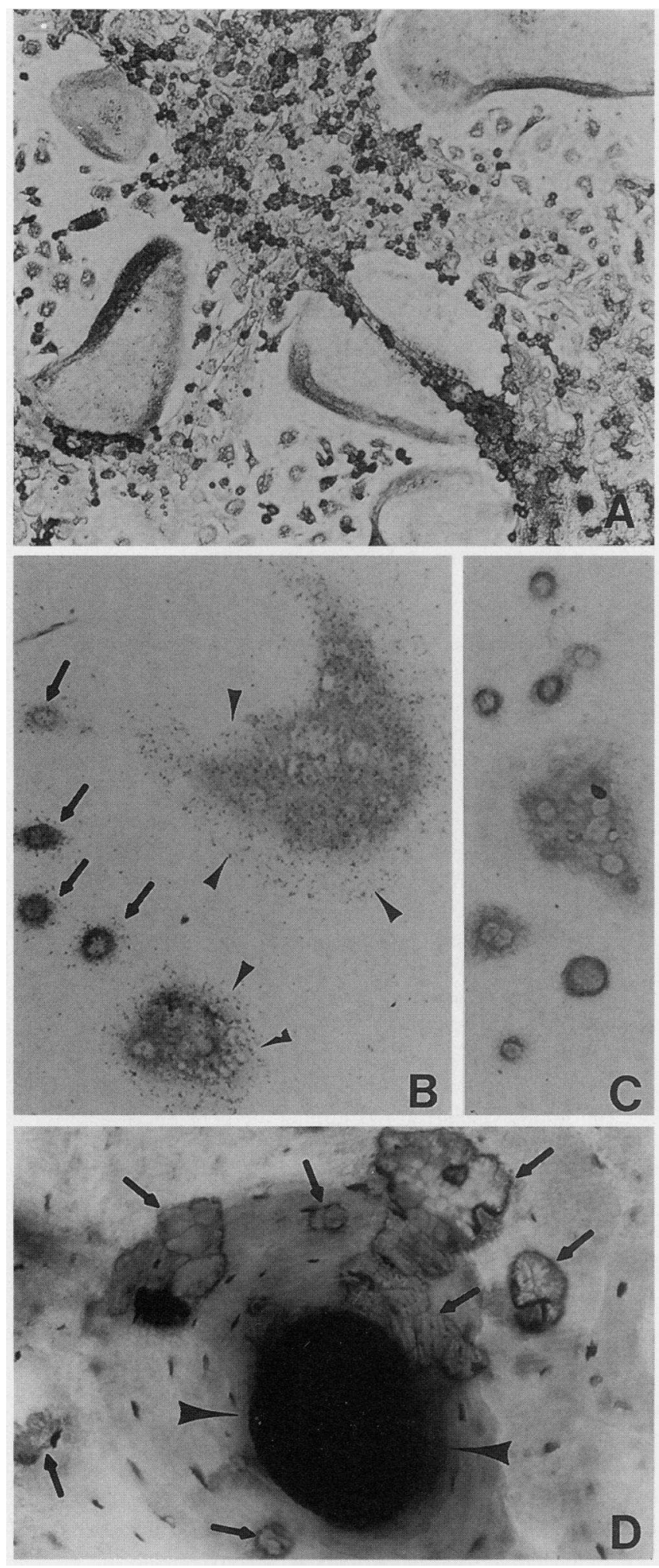

Figure 1. (A) Formation of TRAP-positive multinucleated cells (X100) in cultures of bone marrow cells incubated with $10 \mathrm{nM} 1,25(\mathrm{OH})_{2} \mathrm{D}_{3}$ for $7 \mathrm{~d}$. ( $B$ and $C$ ) Autoradiography of ${ }^{125} \mathrm{I}$-calcitonin binding to bone marrow cultures (X200). Binding was observed in both mono-(arrows) and multinucleated (arrowheads) TRAP-positive cells $(B)$. The specificity of the binding was demonstrated by the lack of grains in cells incubated with excess of unlabeled calcitonin $(C)$. $(D)$ Resorption lacunae formed by bone marrow cells cultured with $10 \mathrm{nM} 1,25(\mathrm{OH})_{2} \mathrm{D}_{3}$ for $7 \mathrm{~d}$ on human cortical bone slices. After cells were removed, the in a manner similar to fresh IL-1 ra (Fig. 4). Similarly, competition ELISA experiments demonstrated that the sera of TNFbpor anti-IL-6 Ab-treated mice decreased the binding of rTNF $\alpha$ and rIL- 6 to the corresponding capture $\mathrm{Ab}$ in a manner similar to fresh TNFbp or fresh $\mathrm{Ab} 20 \mathrm{~F} 3$. These data demonstrate that at $2 \mathrm{wk}$ the sera of treated mice were able to neutralize the corresponding cytokine.

Bone marrow cells were recovered at the end of the treatment period and cultured in presence of $10 \mathrm{nM} 1,25(\mathrm{OH})_{2} \mathrm{D}_{3}$ for $7 \mathrm{~d}$. Table II shows that the increase in the number of bone marrow cells associated with ovx was prevented by each of the three cytokine inhibitors. Fig. 5 shows that the increase in MNC formation induced by ovx was blocked by all treatments. In these experiments the potency of IL-1 ra was similar to that of TNFbp, and superior to that of IL-6. As a result, the IL-1 ra and TNFbp treated groups produced a number of MNCs similar to that of sham control groups, whereas bone marrow cells from ovx mice treated with anti-IL-6 Ab formed significantly more MNCs than the corresponding sham control group. Treatment with both IL-1ra and TNFbp caused a further, although not significant, inhibition of MNC formation, thus suggesting that the effect of the two inhibitors is partially additive. Moreover, while IL-1 ra and TNFbp had no effects on MNC formation in sham-operated mice, the percent change in MNC formation induced by the anti-IL- $6 \mathrm{Ab}$ was similar in ovx and shamoperated animals, suggesting that the contribution of IL-6 to osteoclastogenesis does not increase with estrogen withdrawal.

To rule out the possibility that the effects of IL-1ra and TNFbp on MNC formation may result from an aspecific response to proteins, additional experiments were performed in which ovx and sham-operated mice were treated with $25 \mathrm{mg} /$ $\mathrm{KgBW}$ per day bovine serum albumin (BSA). These experiments revealed that BSA did not affect MNC formation (data not shown).

We then investigated whether the in vitro addition of the cytokine inhibitors to the bone marrow cultures from untreated mice decreases MNC formation. For these experiments bone marrow cells obtained from untreated ovx and sham-operated mice were cultured for $7 \mathrm{~d}$ as described in the methods. Fig. 6 shows that IL-1 ra $(5-50 \mu \mathrm{g} / \mathrm{ml})$ and TNFbp $(0.5-5.0 \mu \mathrm{g} / \mathrm{ml})$ were equally potent in decreasing $\mathrm{MNC}$ formation in cultures derived from both ovx and sham-operated mice. In contrast, in vitro treatment with the anti-IL-6 Ab $20 \mathrm{~F} 3(5-35 \mu \mathrm{g} / \mathrm{ml})$ or $17 \beta$ estradiol $\left(10^{-9}-10^{-6} \mathrm{M}\right)$ (not shown) had no effect.

To determine whether IL-1 and TNF are involved in the proliferation or the differentiation of OC precursors, additional experiments were performed in which bone marrow cultures from intact mice were treated with IL-1ra, TNFbp, or anti-IL$6 \mathrm{Ab}$ for selected periods. The duration of the proliferative phase was determined in preliminary experiments which showed that MNC formation was completely blocked by treatment with $0.2-$ $1.0 \mathrm{mM}$ hydroxyurea during the first $4 \mathrm{~d}$ of culture. In contrast, addition of $1.0 \mathrm{mM}$ hydroxyurea during the last $3 \mathrm{~d}$ of culture decreased MNC formation by $\sim 20 \%$ (data not shown). These findings, which are similar to those of Tanaka et al. (53), indicate that proliferation of bone marrow cells takes place mainly in the first $4 \mathrm{~d}$ of culture.

bone slice was stained with toluidine blue to show the resorption lacunae (arrows) (X100). Arrowheads indicate a haversian canal. 

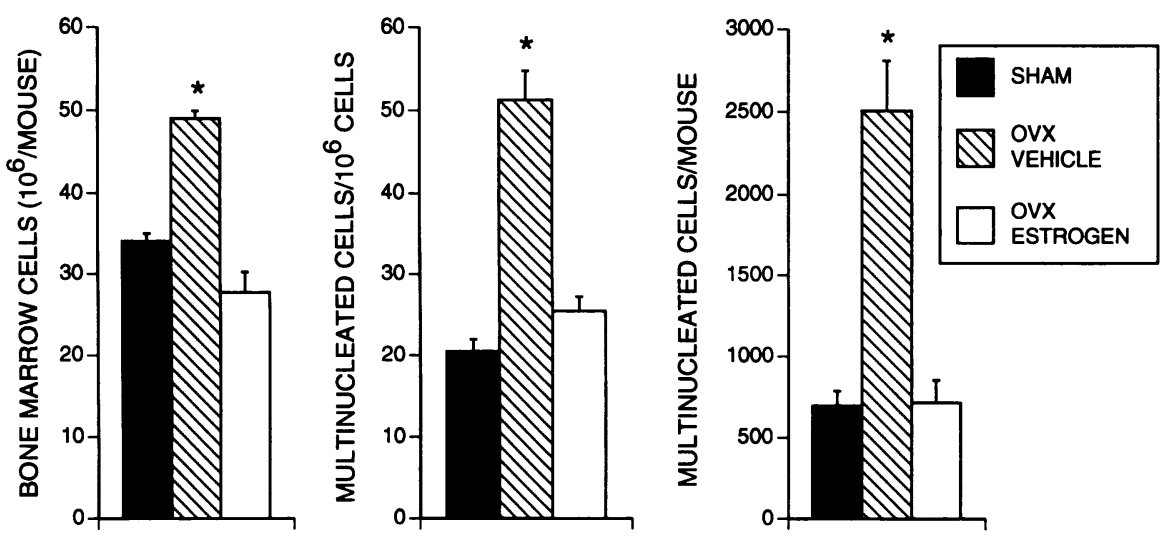

Figure 2. Effect of ovx (mean \pm SEM) on MNC formation in vitro. Bone marrow cells obtained from mice ( $n=6$ per group) killed 2 wk after ovx or sham operation were cultured for $7 \mathrm{~d}$ with $10 \mathrm{nM} 1,25(\mathrm{OH})_{2} \mathrm{D}_{3}$. Ovx increased the number of bone marrow cells and the formation of MNCs. $\quad * P<0.01$ compared with sham-operated mice. Representative results are presented from 1 of 10 experiments. Similar results were obtained when the data were expressed as the mean \pm SEM of the percent change from controls in replicate experiments.

Table III shows that treatment with either IL-1 ra or TNFbp for the first $4 \mathrm{~d}$ of culture decreased MNC formation in a manner similar to treatment during the last $3 \mathrm{~d}$ of culture, a period corresponding to the differentiation phase. In contrast, anti-IL$6 \mathrm{Ab}$ had no effects at any time. These data indicate that IL-1 and TNF contribute to both the proliferation and the differentiation of MNCs precursors.

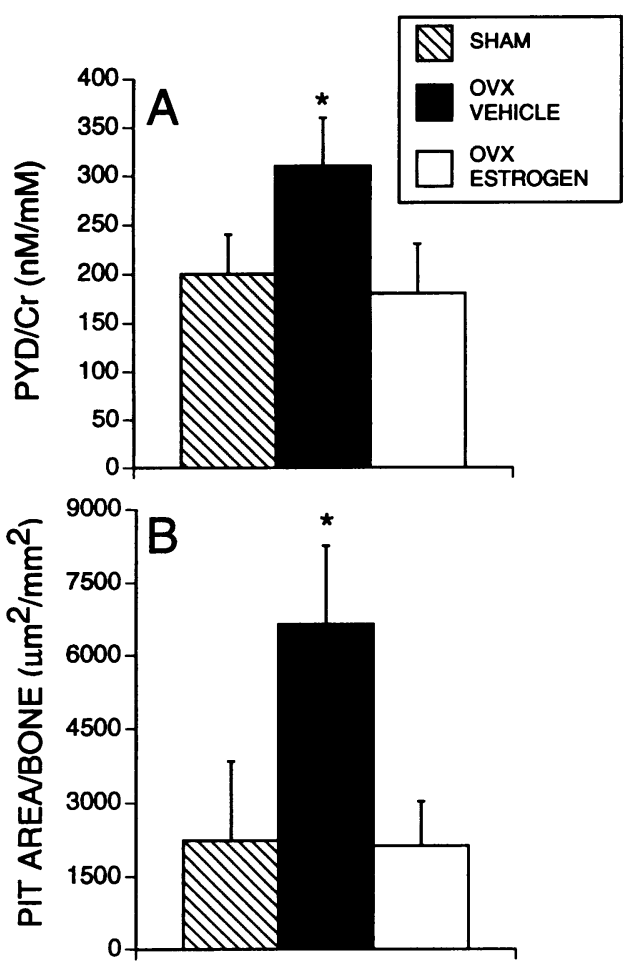

Figure 3. Effects of ovx (mean \pm SEM) on the urinary excretion of pyridinoline crosslinks $(A)$ and on the formation of resorption pits $(B)$ 2 wk after ovx or sham operation urine samples were collected from six mice per group and used for PYD measurements. Bone marrow cells were then harvested from all mice, seeded in triplicate on slices of human bone and cultured for $7 \mathrm{~d}$. Cells were then removed and the bone slices stained with toluidine blue. The area of pit resorption was measured as described in the methods. Results were expressed as the mean $( \pm S E M)$ of the area resorbed divided by the total area of the bone slice. Representative results are presented from one of three experiments. $* P<0.01$ compared with sham-operated mice. Similar results were obtained when the data were expressed as the mean \pm SEM of data from replicate experiments.
Effect of in vivo treatment with IL-Ira, TNFbp and anti-IL$6 \mathrm{Ab}$ on in vivo and in vitro bone resorption. To investigate the effects of IL-1ra, TNFbp and anti-IL-6 Ab on OC activity, we investigated the effects of these inhibitors on bone resorption in vivo by measuring the urinary excretion of PYD. 2 wk after surgery PYD excretion was (Fig. 7) significantly higher in untreated ovx mice than in sham-operated mice. Treatment with IL-1 ra and TNFbp decreased pyridinoline excretion in a manner similar to estrogen. In contrast, treatment with anti-IL-6 Ab had no effects. Treatment with each of the three cytokine inhibitors did not alter PYD excretion in sham-operated mice. These data demonstrate that IL-1 ra and TNFbp prevent the effects of ovx on bone resorption in vivo.

We then assessed the impact of cytokine inhibition in vivo on bone resorption in vitro by measuring the ability of IL-1ra, TNFbp and anti-IL-6 Ab to decrease the excavation of resorption pits. These experiments (Fig. 8) confirmed the data shown in Fig. $3 B$ as they demonstrated that during the 7-d culture period bone marrow cells obtained from ovx mice excavated a larger bone area than cells from sham-operated mice. IL-1 ra and TNFbp completely prevented the ovx-induced increase in the area resorbed by the OC-like cells. The area resorbed by cells obtained from ovx mice treated with these agents was, in fact, similar to that excavated by cells from control sham-operated mice. Unexpectedly, simultaneous treatment with IL-1 ra and TNFbp was less effective, although not significantly, than treatment with TNFbp only. Treatment with anti-IL-6 Ab also decreased pit area, although cells from ovx mice treated with the anti-IL-6 Ab formed more abundant resorption pits than those from sham mice treated with control antibody. None of the three cytokine inhibitors decreased the excavation of resorption pits in sham-operated mice.

Since the magnitude of the inhibitory effect on in vitro bone resorption of each substance was similar to that on osteoclastogenesis, the data suggest that IL-1, IL-6, and TNF modulate bone resorption by regulating osteoclastogenesis, rather than the resorption activity of individual OCs.

\section{Discussion}

In this study we have investigated the effects of IL-1ra, TNFbp, and the anti-IL-6 Ab 20F3 on osteoclastogenesis and bone resorption. IL-1ra is a specific competitive inhibitor of IL1 which does not possess IL-1 agonistic effects (54). TNFbp is a divalent inhibitor of TNF which binds specifically and with equal affinity to both TNF $\alpha$ and TNF $\beta$, and, at the dose used 

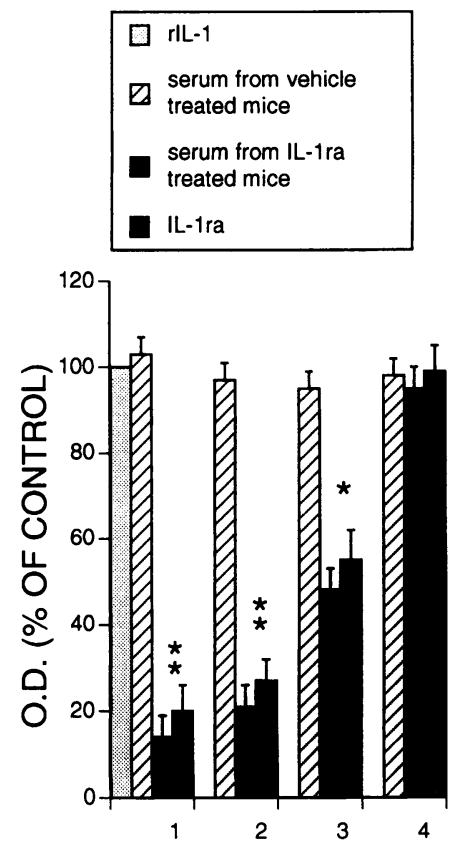
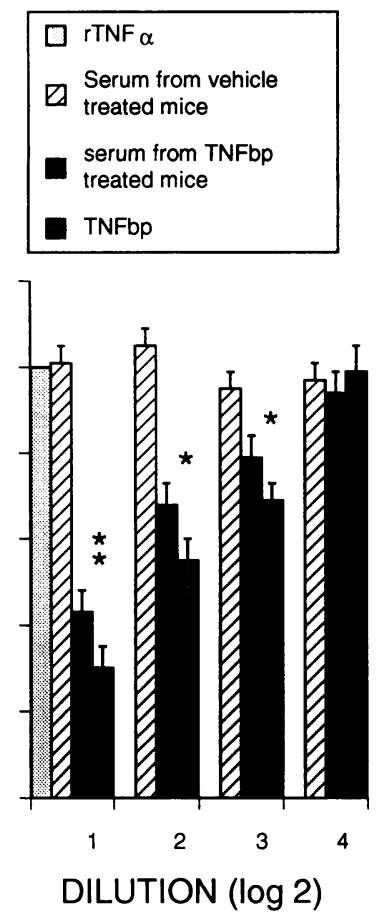
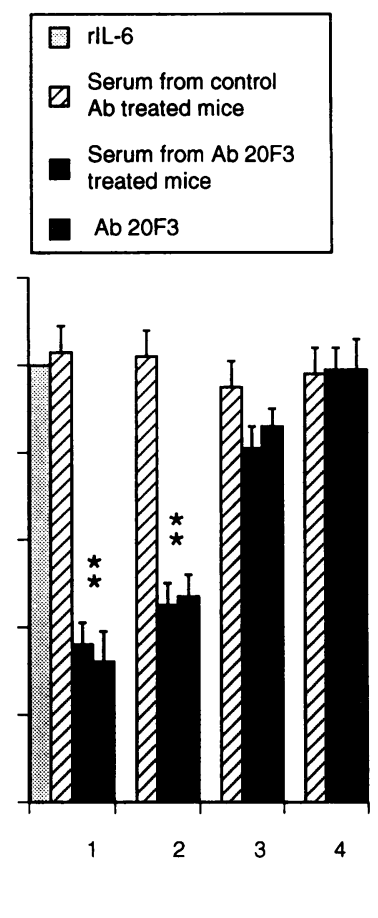

Figure 4. Effect (mean \pm SEM) of serum from IL-1 ra treated mice (left panel) on IL- $1 \beta$-induced augmentation of D10 cell proliferation and of serum from TNFbp (middle panel) and $\mathrm{Ab} 20 \mathrm{~F} 3$ treated mice (right panel) on TNF $\alpha$ and IL- 6 binding to immobilized anti-TNF $\alpha$ and anti-IL$6 \mathrm{Ab}$, respectively. For the IL-1 neutralization experiments sera $(12.5 \mu \mathrm{l})$ obtained at the end of the treatment period from ovx mice treated with IL1ra or vehicle and fresh rIL-1ra (2.5 ng) were serially diluted (1:2) and added to D10 cells seeded in triplicate in 96-wells plates. Human rIL- $1 \beta$ (7.5 pg) was then added to the each well and D10 cell proliferation measured after $3 \mathrm{~d}$ of incubation as described in Methods. For the TNF and IL-6 neutralization experiments sera $(20 \mu \mathrm{l})$ from ovx mice treated with either TNFbp, Ab 20F3 or control substances and fresh TNFbp $(100 \mathrm{pg} / \mathrm{ml})$ or $\mathrm{Ab} 20 \mathrm{~F} 3(100 \mathrm{ng} / \mathrm{ml})$ were serially diluted (1:2) and incubated with rTNF $\alpha(1 \mathrm{ng} / \mathrm{ml})$ or rIL-6 $(0.6 \mathrm{ng} / \mathrm{ml})$

and then added to culture wells coated with anti-TNF or anti-IL-6 capture antibodies. Biotinylated anti-cytokine were then added to the plates and cytokine binding measured as described in Methods. Results (mean of three experiments, $n=6$ mice per group) are expressed as percent change in D10 cell proliferation and as percent change in Ab binding. The OD value obtained with rIL-1, rTNF $\alpha$ or rIL-6 was arbitrarily set at $100 \%$.

$* P<0.05$ and $* * P<0.01$ compared with serum from control treated mice.

in this study, prevents endotoxin-induced lethality in mice (unpublished observations). The anti-IL-6 Ab 20F3 has been previously used with the same modalities as in this study, to neutralize IL-6 in vivo for up to $4 \mathrm{wk}(8)$. In agreement with these observations we have found that the serum of mice treated with anti-IL-6 Ab was capable of neutralizing rIL-6 in a manner similar to fresh anti-IL-6 Ab. In this study we have also found that the infusion of IL-1 ra resulted in serum IL-1 ra levels 16 times higher than that required to block ${ }^{45} \mathrm{Ca}$ release in vitro from mouse bone stimulated with $100 \mathrm{pg} / \mathrm{ml}$ of IL-1 (28) and that the injection of $\mathrm{TNFbp}$ resulted is serum type I TNF receptor levels 5-10 times higher than the amount of recombinant TNF $\alpha$ required to stimulate bone resorption in vitro (15).

Assays of cytokines in the culture media of bone marrow cells revealed that ovx is associated with an increased production of IL- 1 and TNF, a finding in keeping with previous rat and human studies of ours and others $(30,31,33,34,37,55)$ but in contrast with those Hustmyer et al. (56) and Zarrabeitia et al. (57) who failed to detect a higher production of IL-1 and TNF in osteoporotic women. We also found that ovx was not associated with an increased bone marrow cell production of IL-6. This is agreement with the studies of Chaudhary et al. (58), Rifas et al. (59) and Rickard et al. (11), but in contrast with that of Jilka et al. (8) who documented an increased production of IL-6 from bone marrow cells from mice killed $28 \mathrm{~d}$ after ovariectomy. Differences in assay techniques (bioassays vs ELISAs and IRMAs) and experimental design (samples obtained 14 vs $28 \mathrm{~d}$ after ovariectomy) are likely to account for these discrepancies. To investigate the role of IL-1, IL-6, and TNF in the increase in bone resorption induced by ovx, we examined the effects of the functional block of these three cytokines on MNCs maturation. Our data show that in ovx mice

Table II. Effect (mean \pm SEM) of In Vivo Treatment with IL-1ra, TNFbp, and Anti IL-6 Antibody on Bone Marrow Cell Number

\begin{tabular}{|c|c|c|c|c|c|}
\hline Group & $\begin{array}{c}\text { Bone } \\
\text { marrow cells } \\
\left(10^{6}\right)\end{array}$ & Group & $\begin{array}{c}\text { Bone } \\
\text { marrow cells } \\
\left(10^{6}\right)\end{array}$ & Group & $\begin{array}{c}\text { Bone } \\
\text { marrow cells } \\
\left(10^{6}\right)\end{array}$ \\
\hline Sham vehicle & $34.0 \pm 1.6$ & Sham vehicle & $31.8 \pm 0.7$ & Sham IgG & $31.8 \pm 1.5$ \\
\hline Sham IL-1ra & $32.9 \pm 1.0$ & Sham TNFbp & $32.1 \pm 1.3$ & Sham Ab $20 \mathrm{~F} 3$ & $34.3 \pm 1.0$ \\
\hline ovx vehicle & $47.3 \pm 1.1$ & ovx vehicle & $44.8 \pm 1.4$ & ovx IgG & $47.1 \pm 0.9$ \\
\hline ovx IL-1 ra & $35.6 \pm 1.9^{*}$ & ovx TNFbp & $36.9 \pm 1.4^{*}$ & ovx Ab $20 \mathrm{~F} 3$ & $35.6 \pm 2.1 *$ \\
\hline ovx estrogen & $23.5 \pm 2.4 \ddagger$ & ovx IL-1ra + TNFbp & $35.1 \pm 1.0^{*}$ & ovx estrogen & $29.3 \pm 3.1 \ddagger$ \\
\hline
\end{tabular}

Data obtained from the representative experiment shown in Fig. 5. $n=6$ mice per group. $* P=<0.05$ compared with ovx controls. $\ddagger P$ $<0.01$ compared with ovx controls. 


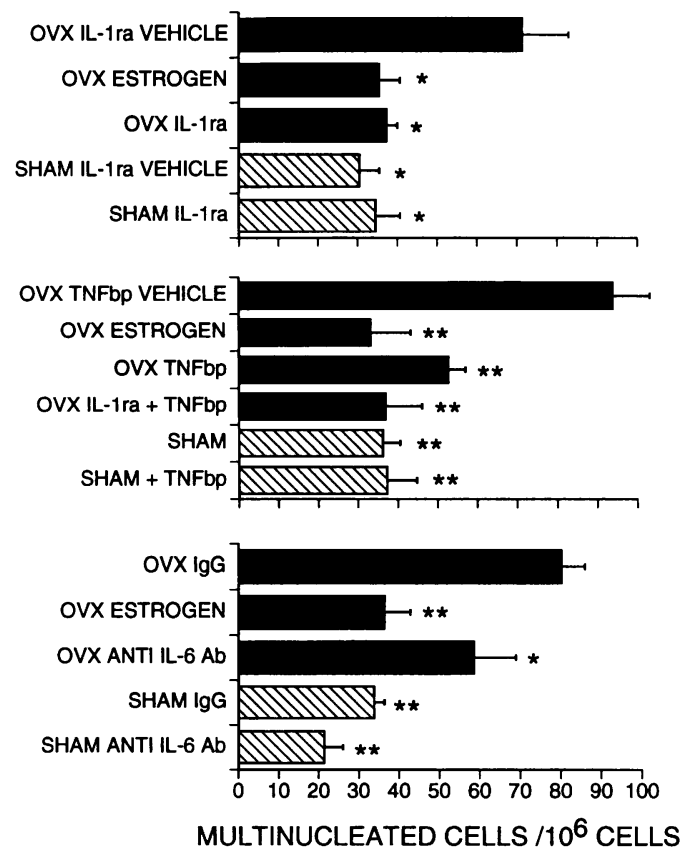

Figure 5. Effect of in vivo treatment (mean \pm SEM) with IL-1ra, TNFbp and anti-IL-6 Ab on MNC formation ( $n=6$ per group). Treatments were started at the time of ovx and continued for $2 \mathrm{wk}$. Bone marrow cells were then harvested and cultured with $10 \mathrm{nM} 1,25(\mathrm{OH})_{2} \mathrm{D}_{3}$ for 7 d. $* P<0.05$ and $* * P<0.01$ compared with ovx controls. Representative results are presented from one of seven experiments. Similar results were obtained when the data were expressed as the mean \pm SEM of the percent change from controls in replicate experiments. In each experiment the number of bone marrow cells was higher in ovx control than in sham control mice.

the proliferation and differentiation of MNCs precursors was blocked each of the three inhibitors, thus demonstrating that IL-1, IL-6, and TNF play a direct role in osteoclastogenesis. Although, the potency of IL-1ra was similar to that of TNFbp,
Table III. Effect of Cytokine Inhibition on the Time Course of MNC Formation

\begin{tabular}{llcc}
\hline & \multicolumn{3}{c}{ Treatment duration } \\
\cline { 2 - 4 } \multicolumn{1}{c}{ Treatment } & Days 1-7 & Days 1-4 & Days 5-7 \\
\hline None & $35.4 \pm 4.2$ & - & - \\
IL-1 ra $(10 \mu \mathrm{g} / \mathrm{ml})$ & $11.3 \pm 3.5^{*}$ & $16.0 \pm 1.4^{*}$ & $15.0 \pm 1.2^{*}$ \\
TNFbp $(2 \mu \mathrm{g} / \mathrm{ml})$ & $15.7 \pm 5.0^{*}$ & $16.0 \pm 4.8^{*}$ & $16.3 \pm 4.4^{*}$ \\
Anti IL-6 ab $(35 \mu \mathrm{g} / \mathrm{ml})$ & $29.3 \pm 2.3$ & $43.5 \pm 6.1$ & $53.5 \pm 2.9$ \\
\hline
\end{tabular}

Data are expressed as $\mathrm{MNCs} / 10^{6}$ cells (mean $\pm \mathrm{SEM}$ ). Osteoclast formation was decreased by the addition of either iL-1 ra and TNFbp during both the proliferative phase (days 1-4) and the differentiative phase (days 5-7) of the MNCs maturation process. ${ }^{*} P<0.05$ compared with controls.

and superior to that of IL- 6 , these data should be interpreted with caution, due to difference in size and structure between the anti-IL-6 antibody, IL-1 ra, and TNFbp. Surprisingly, the effects of IL-1 ra and TNFbp in ovx mice were scarcely additive, presumably because the in vivo experiments were conducted using maximally effective doses of each inhibitor. The complex effects of IL-1 and TNF on each other's synthesis and receptor expression (60) could also account for this observation.

IL-1 ra and TNFbp had no effects on sham-operated animals, indicating that these agents specifically block estrogen regulated MNC formation and activation. In contrast, treatment of with the anti-IL-6 Ab 20F3, carried out as described by Jilka et al. (8), decreased MNC formation in both ovx and sham-operated mice. Several differences in methodology may account for this discrepancy. Among them are the different strain and age of the mice and the length of the culture period. Moreover, while we expressed our results as $\mathrm{MNCs} / 10^{6}$ cells, Jilka et al. expressed theirs as MNCs/femur.

The contribution of IL-6 to increase in bone resorption induced by ovariectomy has recently been further investigated by
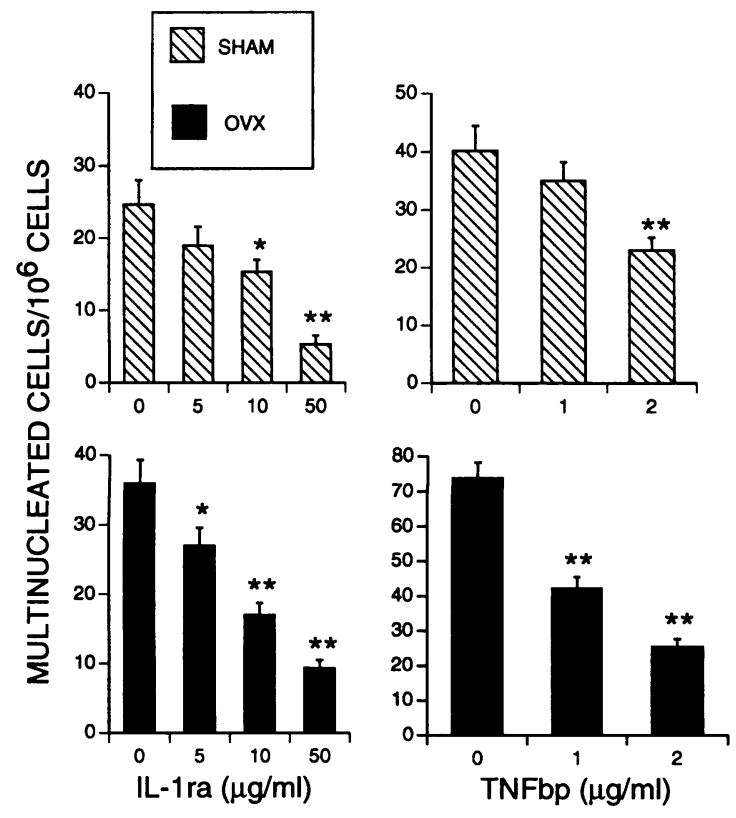

Figure 6. Effect of in vitro treatment (mean \pm SEM) with IL-1 ra, TNFbp, and anti-IL-6 Ab on MNC formation. Bone marrow cells obtained from mice $(n=4$ per group) killed 2 wk after ovx or sham operation were cultured for $7 \mathrm{~d}$ with $10 \mathrm{nM} 1,25(\mathrm{OH})_{2} \mathrm{D}_{3}$ in presence of either IL-1 ra, the anti-mouse IL-6 Ab 20F3, or TNFbp. Representative results are presented from one of six experiments. ${ }^{*} P<0.05$ compared with controls. Similar results were obtained when the data were expressed as the mean \pm SEM of the percent change from controls in replicate experiments. 


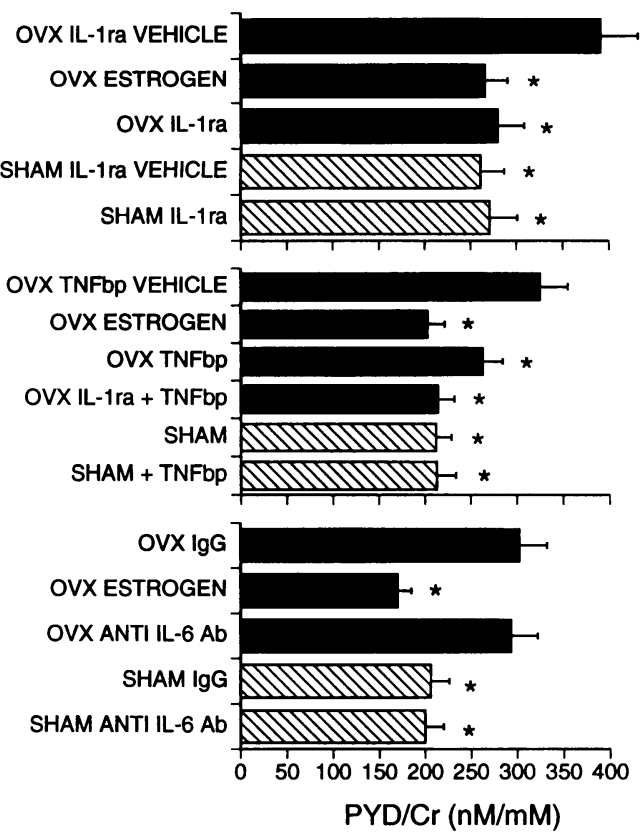

Figure 7. Effect of in vivo treatment (mean \pm SEM) with IL-1 ra, TNFbp and anti-IL-6 $\mathrm{Ab}$ on the urinary excretion of pyridinoline crosslinks. Mice were ovx or sham-operated and treated with either IL-1 ra, the anti-IL-6 Ab 20 F3, TNFbp or estrogen for 2 wk starting at the time of surgery. Representative results are presented from one of three experiments $* P<0.05$ compared with ovx controls. Similar results were obtained when the data were expressed as the mean \pm SEM of data from replicate experiments.

Poli et al. (61) in a study demonstrating that IL-6 deficient mice fail to lose bone in response to ovariectomy. Our findings are not directly comparable with those of Poli et al. because of the profound differences in the two experimental models. Postmenopausal osteoporosis results, in fact, from the impact of estrogen deficiency on a normally developed skeleton, a condition which can be replicated in normal mice by ovariectomy. In contrast, IL-6-deficient mice are characterized by bone modeling and remodeling defects which ensue during fetal development and lead to the formation of an altered mature skeleton.

Recently, we have reported that treatment with IL-1 ra decreases bone loss and bone resorption in ovx rats (37), thus demonstrating that IL-1 plays a direct, causal role in the bone loss induced by estrogen deficiency. In this study, we have investigated the mechanism of the effect of IL-1 ra and demonstrated that IL-1ra blocks the proliferation and differentiation of MNCs precursors. IL-1 ra also decreased the urinary excretion of PYD and the formation of resorption pits. However, since the inhibitory effect on pit formation was proportional to that on MNC formation, the data indicate that the main effect of IL-1 ra is not to decrease the resorptive activity of each OC, but rather to regulate the number of OC precursors which reach functional maturity. Our data also show that inhibition of TNF with TNFbp inhibits MNC formation on bone resorption in a manner similar to IL-1 ra and estrogen. These data confirm earlier studies in vitro indicating a substantial functional overlap between IL-1 and TNF (52).

Although the source and the cellular target of IL-1 and TNF have not been investigated in this study, our working hypothesis is that estrogen deficiency increases the production of IL-1 and TNF from cells of the monocyte/macrophage lineage. These

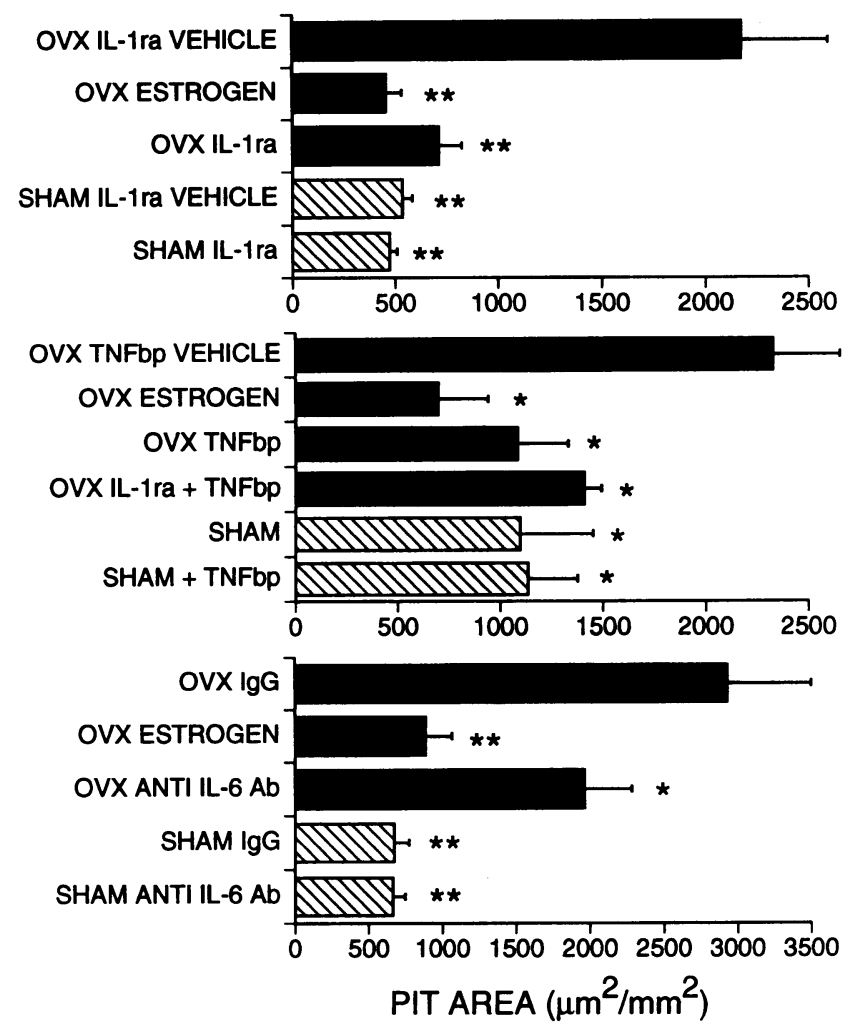

Figure 8. Effect of in vivo treatment with IL-1 ra, TNFbp, and anti-IL$6 \mathrm{Ab}$ on resorption pits formation. Mice were ovx or sham-operated and treated with either IL-1 ra, the anti-IL-6 Ab 20F3, TNFbp, or estrogen for $2 \mathrm{wk}$ starting at the time of surgery. Bone marrow cells were then seeded in triplicate on human bone slices and cultured for $7 \mathrm{~d}$. Cells were then removed and the bone slices stained with toluidine blue as described in Methods. The area of pit resorption was measured as described in Methods. Results were expressed as the mean ( \pm SEM) of the area resorbed in each one of the triplicate cultures. Representative results are presented from one of three experiments $* P<0.05$ and ** $P<0.01$ compared with ovx controls. Similar results were obtained when the data were expressed as the mean \pm SEM of the percent change from controls in replicate experiments.

cytokines could, in turn, stimulate stromal cells to produce membrane-bound and soluble factors such as M-CSF and IL11 which regulate the proliferation and differentiation of the hemopoietic MNC precursors (62). This hypothesis is supported by studies which demonstrate the capacity of IL- 1 and TNF to stimulate the stromal cell production of M-CSF and IL-11 (6366) and the essential role of the latter two factors in regulating the proliferation and differentiation of MNC progenitors $(53,66-$ 69). Moreover, the recent study of Glowacki et al. (66) demonstrating that MNC precursors are the target of IL-6 suggests that IL- 6 may also be one of the cytokines produced by stromal cells in response to IL- 1 and TNF $\alpha$, which regulates the early differentiation steps of the hemopoietic MNC precursors. According to this hypothesis, the effects of IL-6 would resemble those of IL-11, which, interestingly, is also not regulated by estrogen (69) and uses gp130 as a signal transducer (70).

Our data also demonstrate that IL-6 plays a role different from that of IL-1 and TNF in bone resorption. In particular, while in vivo inhibition of IL-1 and TNF blocked bone resorption in vitro and in vivo, treatment with the anti-IL-6 Ab decreased pit formation, but not PYD excretion. Since the regula- 


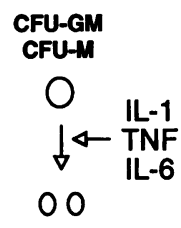

EARLY OC PRECURSORS 000

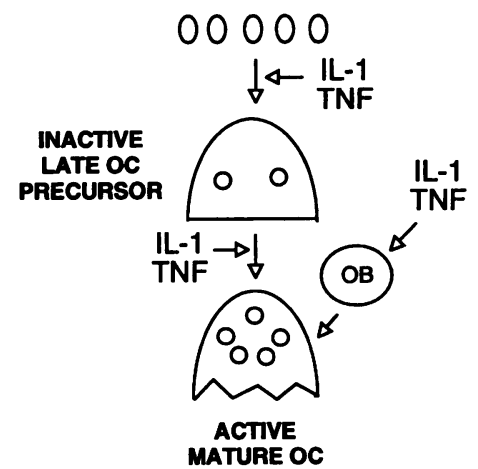

Figure 9. Hypothetical view of the effects of IL-1, TNF, and IL- 6 on OC differentiation and activation. The upper part of the diagram represents the proliferation of hemopoietic OC precursors originating from cells of the CFU-GM or CFU-M lineage. This step is induced by several cytokines including IL-1, IL-6, and TNF. The differentiation of these cells into inactive, but more mature OCs is stimulated by IL1 and TNF, but not IL-6. OC activation, a process which may coincide with the final maturation process, is rapidly induced by IL-1 and TNF via osteoblastic cells. In vivo treatment with anti-IL$6 \mathrm{Ab}$ results in the selective depletion of early OC pre-

cursors and in a decreased ability of bone marrow cells to generate bone resorbing OCs. The maturation of cells "downstream" to the IL-6 dependent steps account for the persistence of an unabated bone resorption in vivo. In vivo treatment with IL-1ra or TNFbp results in the depletion of early and late OC precursors and in the block of both in vitro and in vivo bone resorption.

tory role of IL-6 is limited to the initial steps of the MNCs differentiation process (21), it could be that the block of IL- 6 in vivo is insufficient for preventing the complete maturation and activation of those cells which are "downstream" with respect to the IL-6-dependent steps (Fig. 9). According to this hypothesis, the lack of change in PYD excretion during the 2wk-long treatment with anti-IL-6 Ab would reflect the maintenance of an unaltered pool of active, mature OCs. Conversely, the decreased pit formation observed with the IL-6 block is likely to reflect the decreased bone marrow content of OC precursors and the resulting decrease in the number of cells which reach functional maturity in vitro (62). From this hypothesis one would predict that inhibition of IL-1 and TNF blocked bone resorption in vivo and in vitro because these cytokines regulate early and late steps of the OC maturation process. Long term studies will be necessary to fully determine the role of IL- 6 in bone resorption and to ascertain whether OC maturation and activation is maintained unaltered in conditions in which IL-6 is chronically blocked.

In conclusion, these data indicate that IL-1 and TNF play a direct role in mediating the effects of ovx on OC formation and bone resorption. The data also suggest that IL- 6 is not essential for increasing bone resorption in the early post-ovx period.

\section{Acknowledgments}

We wish to thank Janet Frazier and Christopher G. Smith at Synergen Inc. for the IL-1 ra and TNFbp assays, Cynthia Brownfield for her technical assistance, and Dr. Patrick Ross for his expert review of the manuscript.

This study was supported by National Institutes of Health grants AR-39706 and AR-41412.

\section{References}

1. 1984. National Institutes of Health Consensus Conference. J. Am. Med. Assoc. 252:799-802.

2. Horowitz, M. 1993. Cytokines and estrogen in bone: anti-osteoporotic effects. Science (Wash. DC). 260:626-627.

3. Raisz, L. G. 1988. Local and systemic factors in the pathogenesis of osteoporosis. N. Engl. J. Med. 318:818-828.

4. Gowen, M., D. D. Wood, E. J. Ihrie, M. K. B. McGuire, and R. G. G. Russell. 1983. An interleukin-1-like factor stimulates bone resorption in vitro. Nature (Lond.). 306:378-380.

5. Lorenzo, J. A., S. L. Sousa, C. Alander, L. G. Raisz, and C. A. Dinarello. 1987. Comparison of the bone-resorbing activity in the supernatants from phytohemaglutinin-stimulated human peripheral blood mononuclear cells with that of cytokines through the use of an antiserum to interleukin 1. Endocrinology. 121:11641170.

6. Stashenko, P., F. E. Dewhirst, M. L Rooney, L. A. Desjardins, and J. D. Heeley. 1987. Interleukin-1 b is a potent inhibitor of bone formation in vitro. $J$. Bone Miner. Res. 2:559-565.

7. Girasole, G., R. L. Jilka, G. Passeri, S. Boswell, G. Boder, D. C. Williams, and S. C. Manolagas. 1992. 17b-estradiol inhibits interleukin-6 production by bone marrow-derived stromal cells and osteoblasts in vitro: A potential mechanism for the antiosteoporotic effect of estrogens. J. Clin. Invest. 89:883-891.

8. Jilka, R. L., G. Hangoc, G. Girasole, G. Passeri, D. C. Williams, J. S. Abrams, B. Boyce, H. Broxmeyer, and S. C. Manolagas. 1992. Increased osteoclast development after estrogen loss: mediation by Interleukin-6. Science (Wash. DC). 257:88-91.

9. Passeri, G., G. Girasole, R. L. Jilka, and S. C. Manolagas. 1993. Increased interleukin- 6 production by murine bone marrow and bone cells after estrogen withdrawal. Endocrinology. 133:822-828.

10. Ralston, S. H., R. G. G. Russell, and M. Gowen. 1990. Estrogen inhibits release of tumor necrosis factor from peripheral blood mononuclear cells in postmenopausal women. J. Bone Miner. Res. 5:983-988.

11. Rickard, D., G. Russell, and M. Gowen. 1992. Oestradiol inhibits the release of tumour necrosis factor but not interleukin 6 from adult human osteoblasts in vitro. Osteoporosis Int. 2:94-102.

12. Bertolini, D. R., G. E. Nedwin, T. S. Bringman, D. D. Smith, and G. R Mundy. 1986. Stimulation of bone resorption and inhibition of bone formation in vitro by human tumor necrosis factor. Nature (Lond.). 319:516-518.

13. Boyce, B. F., T. B. Aufdemorte, I. R. Garrett, A. J. P. Yates, and G. R. Mundy. 1989. Effects of interleukin-1 on bone turnover in normal mice. Endocrinology. 125:1142-1150.

14. Sabatini, M., B. Boyce, T. Aufdemorte, L. Bonewald, and G. R. Mundy. 1988. Infusions of recombinant human interleukin 1 alpha and beta cause hypercalcemia in normal mice. Proc. Natl. Acad. Sci. USA. 85:5235-5239.

15. Thomson, B. M., G. R. Mundy, and T. J. Chambers. 1987. Tumor necrosis factor $\alpha$ and $\beta$ induce osteoblastic cells to stimulate osteoclastic bone resorption. J. Immunol. 138:775-779.

16. Lerner, U. H. and A. Ohlin. 1993. Tumor necrosis factors alpha and beta can stimulate bone resorption in cultured mouse calvariae by a prostaglandinindependent mechanism. J. Bone Miner. Res. 8:147-155.

17. Thomson, B. M., J. Saklatvala, and T. J. Chambers. 1986. Osteoblasts mediate interleukin 1 stimulation of bone resorption by rat osteoclasts. J. Exp. Med. 164:104-112.

18. Pfeilschifter, J., C. Chenu, A. Bird, G. R. Mundy, and G. D. Roodman. 1989. Interleukin-1 and tumor necrosis factor stimulate the formation of human osteoclast-like cells in vitro. J. Bone Miner. Res. 4:113-118.

19. van der Pluijm, G., W. Most, L. van der Wee-Pals, H. de Groot, S. Papapoulos, and C. Lowik. 1991. Two distinct effects of recombinant human tumor necrosis factor-alpha on osteoclast development and subsequent resorption of mineralized matrix. Endocrinology. 129:1596-1604.

20. Tamura, T., N. Udagawa, N. Takahashi, C. Miyaura, S. Tanaka, Y. Yamada, Y. Koishihara, Y. Ohsugi, K. Kumaki, T. Taga, T. Kishimoto, and T. Suda. 1993. Soluble Interleukin- 6 receptor triggers osteoclast formation by interleukin6. Proc. Natl. Acad. Sci. USA. 90:11924-11928.

21. Roodman, G. D. 1992. Interleukin-6: An osteotropic factor? J. Bone Miner. Res. 7:475-478.

22. Lowik, C. W. G. M., G. Van der Plujim, H. Bloys, K. Hoekeman, O. L. M. Bijvoet, L. A. Aarden, and S. E. Papapoulos. 1993. Parathyroid hormone (PTH) and PTH-like protein (PLP) stimulate IL-6 production by osteogenic cells: a possible role of interleukin-6 in osteoclastogensis. Biochem. Biophys. Res. Commun. 162:1546-1552.

23. Bellido, T., G. Girasole, G. Passeri, X. P. Yu, A. Mocharla, R. L. Jilka A. Notides, and S. C. Manolagas. 1993. Demonstration of estrogen and vitamin $\mathrm{D}$ receptors in bone marrow-derived stromal cells: upregulation of the estrogen receptor by 1,25-dihydroxyvitamin-D3. Endocrinology. 133:553-562.

24. Eriksen, E. F., D. S. Colvard, N. J. Berg, M. L. Graham, K. G. Mann, T. C. Spelsberg, and B. L. Riggs. 1988. Evidence of estrogen receptors in normal human osteoblast-like cells. Science (Wash. DC). 241:84-86.

25. Komm, B. S., C. M. Terpening, D. J. Benz, K. A. Graeme, A. Gallegos, M. Korc, G. L. Greene, B. W. O'Mally, and M. R. Haussler. 1988. Estrogen 
binding, receptor mRNA, and biologic response in osteoblast-like osteosarcoma cells. Science (Wash. DC). 241:81-83.

26. Oursler, M. J., P. Osdoby, J. Pyfferoen, B. L. Riggs, and T. C. Spelsberg. 1991. Avian osteoclasts as estrogen target cells. Proc. Natl. Acad. Sci. USA. 88:6613-6617.

27. Oursler, M. J., L. Pederson, J. Pyfferoen, P. Osdoby, L. Fitzpatrick, and T. C. Spelsberg. 1993. Estrogen modulation of avian osteoclast lysosomal gene expression. Endocrinology. 132:1373-1380.

28. Seckinger, P., J. Klein-Nulend, C. Alander, R. C. Thompson, J-M. Dayer, and L. G. Raisz. 1990. Natural and recombinant human IL-1 receptor antagonists block the effects of IL-1 on bone resorption and prostaglandin production. $J$. Immunol. 145:4181-4184.

29. Ralston, S. H. 1994. Analysis of gene expression in human bone biopsies by polymerase chain reaction: evidence for enhanced cytokine expression in postmenopausal osteoporosis. J. Bone Miner. Res. 9:883-890.

30. Pacifici, R., L. Rifas, R. McCracken, I. Vered, C. McMurtry, L. V. Avioli, and W. A. Peck. 1989. Ovarian steroid treatment blocks a postmenopausal increase in blood monocyte interleukin 1 release. Proc. Natl. Acad. Sci. USA. 86:23982402.

31. Pacifici, R., C. Brown, E. Puscheck, E. Friedrich, E. Slatopolsky, D Maggio, R. McCracken, and L. V. Avioli. 1991. Effect of surgical menopause and estrogen replacement on cytokine release from human blood mononuclear cells. Proc. Natl. Acad. Sci. USA. 88:5134-5138.

32. Pacifici, R. 1992. Is there a causal role of IL-1 in postmenopausal bone loss? Calcif. Tissue. Int. 50:295-299.

33. Pioli, G., G. Basini, M. Pedrazzoni, G. Musetti, V. Ulietti, D. Bresciani, P. Villa, A. Bacci, D. Hughes, G. Russell, and M. Passeri. 1992. Spontaneous release of Interleukin-1 and interleukin- 6 by peripheral blood monocytes after ovariectomy. Clin. Sci. 83:503-507.

34. Matsuda, T., K. Matsui, Y. Shimakoshi, Y. Aida, and S. Hukuda. 1991. 1Hydroxyethilidene-1, 1-bisphosphonate decreases the postovariectomy-enhanced interleukin 1 production by peritoneal macrophages in adult rats. Calcif. Tissue. Int. 49:403-406.

35. Kaneki, M., T. Nakamura, A. Masuyama, J. T. Chen, Y. Seimiya, M. Shiraki, Y. Ouchi, and H. Orimo. 1991. The effect of menopause on IL-1 and IL-6 release from peripheral blood monocytes. J. Bone Miner. Res. 6:76a. (Abstr.)

36. Choen-Solal, M. E., A. M. Graulet, M. A. Denne, J. Gueris, D. Baylink, and M. C. de Vernejoul. 1993. Peripheral monocyte culture supernatants of menopausal women can induce bone resorption: involvment of cytokines. J. Clin. Endocrinol. Metab. 77:1648-1653.

37. Kimble, R. B., J. L. Vannice, D. C Bloedow, R. C Thompson, W. Hopfer V. Kung, C. Brownfield, and R. Pacifici. 1994. Interleukin-1 receptor antagonist decreases bone loss and bone resorption in ovariectomized rats. J. Clin. Invest. 93:1959-1967

38. Dinarello, C. A. and R. C. Thompson. 1991. Blocking IL-1: interleukin 1 receptor antagonist in vivo and in vitro. Immunol. Today. 12:404-410.

39. Hannum, C. H., C. J. Wilcox, W. P. Arend, F. G. Joslin, D. J. Dripps P. L. Heimdal, L. G. Armes, A. Sommer, S. P. Eisenberg, and R. C. Thompson 1990. Interleukin-1 receptor antagonist activity of a human interleukin-1 inhibitor Nature (Lond.). 343:336-340.

40. Carter, D. B., M. R. Deibel,Jr., C. J. Dunn, C.-S. C. Tomich, A. L. Laborde, J. L. Slightom, A. E. Berger, M. J. Bienkowski, F. F. Sun, R. N McEwan, P. K. W. Harris et al. 1990. Purification, cloning, expression and biological characterization of an interleukin-1 receptor antagonist protein. Nature (Lond.). 344:633-638.

41. Arend, W. P., F. G. Joslin, R. C. Thompson, and C. H. Hannum. 1989. An IL-1 inhibitor from human monocyutes. J. Immunol. 143:1851-1858.

42. Arend, W. P. 1991. Interleukin 1 receptor antagonist: a new member of the interleukin 1 family. J. Clin. Invest. 88:1445-1451.

43. Takahashi, N., H. Yamana, S. Yoshiki, G. D. Roodman, G. R. Mundy S. J. Jones, A. Boyde, and T. Suda. 1988. Osteoclast-like cell formation and its regulation by osteotropic hormones in mouse bone marrow cultures. Endocrinology. 122:1373-1382.

44. Takahashi, N., T. Akatsu, T. Sasaki, G. C. Nicholson, J. M. Moseley, T. J. Martin, and T. Suda. 1988. Induction of calcitonin receptors by 1a, 25dihydroxyvitamin $D_{3}$ in osteoclast-like multinucleated cells formed from mouse bone marrow cells. Endocrinology. 123:1504-1510.

45. Boyde, A., N. N. Ali, and S. J. Jones. 1984. Resorption of dentine by isolated osteoclasts in vitro. Br. Dent. J. 156:216-220.

46. Uebelhart, D., E. Gineyts, M. C. Chapuy, and P. D. Delmas. 1990. Urinary excretion of pyridinium crosslinks: a new marker of bone resorption in metabolic bone disease. Bone Miner. 8:87-96.

47. Seyedin, S. M., V. T. Kung, Y. N. Daniloff, R. P. Hesley, B. Gometz, L. A. Nielsen, H. N. Rosen, and R. F. Zuk. 1993. Immunoassay of urinary pyridinoline: the new marker of bone resorption. J. Bone Miner. Res. 8:635-641.
48. Sheehan, K. C., N. H. Ruddle, and R. D. Schreiber. 1989. Generation and characterization of hamster monoclonal antibodies that neutralize murine tumor necrosis factors. J. immunol. 142:3884-3893.

49. Malyak, M., F. G. Joslin, E. P. Verderber, S. P. Eisenberg, and W. P. Arend. 1992. IL-1 ra ELISA: reduction and alkylation of synovial fluid eliminates interference by IgM rheumathoid factors. J. Immunol. Methods. 140:281-288.

50. Haskill, S., C. Johnson, D. Eierman, S. Becker, and K. Warren. 1988. Adherence induces selective mRNA expression of monocyte mediators and protooncogenes. J. Immunol. 140:1690-1694.

51. Fuhlbrigge, R. C., D. D. Chaplin, J.-M. Kiely, and E. R. Unanue. 1987 Regulation of interleukin 1 gene expression by adherence and lipopolysaccharide. J. Immunol. 138:3799-3802.

52. Dinarello, C. A. 1989. Interleukin-1 and its biologically related cytokines Adv. Immunol. 44:153-205.

53. Tanaka, S., N. Takahashi, N. Udagawa, T. Tamura, T. Akatsu, E. R. Stanley, T. Kurokawa, and T. Suda. 1993. Macrophage colony-stimulating factor is indispensable for both proliferation and differentiation of osteoclast progenitors. J. Clin. Invest. 91:257-263.

54. Arend, W. P., H. G. Welgus, R. C. Thompson, and S. P. Eisenberg. 1990. Biological properties of recombinant human monocyte-derived interleukin 1 receptor antagonist. J. Clin. Invest. 85:1694-1697.

55. Fiore, C. E., Falcidia.E, R. Foti, M. Motta, and C. Tamburino. 1993. Differences in the time course of the effects of oophorectomy in women on parameters of bone metabolism and Interleukin-1 levels in the circulation. Bone Miner. 20:79-85.

56. Hustmyer, F. G., E. Walker, X. P. Yu, G. Girasole, Y. Sakagami, M Peacock, and S. C. Manolagas. 1993. Cytokine production and surface antigen expression by peripheral blood mononuclear cells in postmenopausal osteoporosis. J. Bone Miner. Res. 8:51-59.

57. Zarrabeitia, M. T., J. A. Riancho, J. A. Amado, J. Napal, and J. GonzalesMacias. 1991. Cytokine production by blood cells in postmenopausal osteoporosis Bone Miner. 14:161-167.

58. Chaudhary, L. R., T. C. Spelsberg, and B. L. Riggs. 1992. Production of various cytokines by normal human osteoblast-like cells in response to interleukin$1 \beta$ and tumor necrosis factor- $\alpha$ : lack of regulation by $17 \beta$-estradiol. Endocrinology. 130:2528-2534.

59. Rifas, L., M. Marcelli, J. S. Kenney, L. Dawson, and L. V. Avioli. 1993 IL-6 is not regulated by ovarian steroid in human bone marrow stromal cells and human osteoblasts with functional estrogen receptors. J. Bone Miner. Res. 8:977A.(Abstr.)

60. Chaplin, D. D., and K. Hogqist. 1992. Interactions between TNF an interleukin-1. In Tumor necrosis factors. The molecules and their emerging role in medicine. B. Beutler, editor. Raven Press, New York. 197-220.

61. Poli, V., R. Balena, E. Fattori, A. Markatos, M. Yamamoto, H. Tanaka, G. Ciliberto, G. A. Rodan, and F. Costantini. 1994. Interleukin-6 deficient mice are protected from bone loss caused by estrogen depletion. EMBO (Eur. Mol Biol. Organ.) J. 13:1189-1196.

62. Suda, T., N. Takahashi, and T. J. Martin. 1992. Modulation of osteoclast differentiation. Endocr. Rev. 13:66-80.

63. Felix, R., H. Fleish, and P. R. Elford. 1989. Bone-resorbing cytokines enhance release of macrophage colony-stimulating activity by osteoblastic cell MC3T3-E1. Calcif. Tissue. Int. 44:356-360.

64. Falkenburg, J. H., M. A. Harrington, R. A. de Paus, W. K. Walsh, R Daub, J. E. Landegent, and H. E. Broxmeyer. 1991. Differential transcriptiona and posttranscriptional regulation of gene expression of the colony-stimulating factors by interleukin-1 and fetal bovine serum in murine fibroblasts. Blood. 78:658-665

65. Yamada, H., S. Iwase, M. Mohri, and D. Kufe. 1991. Involvment of a nuclear factor-kappa B-like protein in induction of the macrophage colony-stimulating factor gene by tumor necrosis factor. Blood. 78:1988-1995.

66. Glowacki, J., N. Shevde, and J. S. Greenberger. 1993. Distinct roles of interleukins-1,-6, and -11 in osteoclastic differentiation of hemopoietic progenitors. J. Bone Miner. Res. 8:A190.

67. Takahashi, N., N. Udagawa, T. Akatsu, H. Tanaka, M. Shionome, and T. Suda. 1991. Role of colony-stimulating factors in osteoclast development. J. Bone Miner. Res. 6:977-985.

68. Kodama, H., A. Yamasaki, M. Nose, S. Niida, Y. Ohgame, M. Abe, M. Kumegawa, and T. Suda. 1991. Congenital osteoclast deficiency in osteopetrotic (op/op) mice is cured by injections of macrophage colony-stimulating factor. $J$. Exp. Med. 173:269-272.

69. Girasole, G., G. Passeri, R. L. Jilka, and S. C. Manolagas. 1994. Interleukin-11: a new cytokine critical for osteoclast development. J. Clin. Invest 93:1516-1524. (Abstr.)

70. Yin, T., T. Taga, M. L. Tsang, K. Yasukawa, T. Kishimoto, and Y. C. Yang. 1993. Involvement of IL-6 signal transducer gp130 in IL-11-mediated signal transduction. J. Immunol. 151:2551-2561. 